\title{
Potensi Wilayah Kota Bukittinggi dalam Pengembangan Usaha Ternak Sapi Potong dan Kontribusinya Terhadap Pendapatan Keluraga
}

\author{
Yetmaneli \\ Fakultus Peternakan Universitas Andalas Padang
}

\begin{abstract}
The aims of the present research were to determine local base resources of Bukittinggi city for beef cattle raising especially feed lot fattening and determine cantribution of beef cattle raising on familiy income. Both secondary and primer data was used quitioner was main instrumen for data gathering. Thirty eight cattle raiser was intervied with was divided into three strata, base on amount of cattle was raised. Benefit cast analysis was used to determined familiy income in cattle raising. The result study shown that the first: Bukittinggi city has several actwantages for beef cattle raising ffeed lot fattening) namely: climate, topografy,marketing aspect, institutinal and local governmem policy. As well as avaibility of feed, water, labor force, medicine and tecnology. The second beef cattle raising (feed lot fattening) has contributed $18,09 \%$ $24,67 \%, 57,41 \%$ respectively strata I. II, III toward family income.
\end{abstract}

Key word: beef cattle raising, local base resources, contribution

\section{Pendahuluan}

Sesuai dengan wilayah pengembangan usaha peternakan di Indonesia, Sumatera Barat termasuk daerah yang memiliki potensi wilayah yang cocok untuk pengembangan komoditas usaha ternak sapi potong. Hal ini menunjukkan adanya kesesuaian antara usaha peternakan dengan kondisi iklim wilayah maupun potensi pasar sehingga didapatkan produk/hasil - hasil peternakan dengan keuntungan yang optimal (Dinas Peternakan Bukittinggi, 1998)

Kota Bukittinggi merupakan salah satu wilayah Sumatera Barat yang memperlihatkan kecendrungan adanya perkembangan usaha pemeliharaan sapi potong, khususnya dengan sistim pemeliharaan "kreman". Sebagai salah satu kota wisata di
Sumatera Barat, Bukittinggi memiliki kekayaan alam dan budaya yang sangat menarik perhatian wisatawan dalam dan luar negeri sehingga sektor wisata merupakan salah satu sektor andalan daerah ini.

Pengembangan sektor pariwisata sebagai prioritas utama pembangunan tentu berkaitan pula dengan pengembangan sektor lain termasuk sektor peternakan. Tingginya wisatawan yang masuk ke daerah ini merupakan pasar yang potensial bagi produk peternakan. Hal ini disebabkan tingginya konsumsi wisatawan akan daging segar yang berkualitas dan tersedia dalam jumlah yang cukup (BIPP Bukittinggi, 2000).

Santosa (1999) menyatakan beberapa kajian penting yang perlu diperhatikan dalam pemilihan wilayah untuk lokasi usaha petemakan adalah

Yetmanefi : Potensi Wilojah Kota Bukittinggi dalan Pengembangan Usaha Ternak sapi Potong dan Kontribusinya TerhadapPendapatan 
keadaan geografi, topografi, ketersediaan tenaga kerja, ketersedian pakan dan air serta kebijakan pemerintah. Secara umum dalam usaha pengembangan ternak sapi potong, Indonesia memiliki potensi wilayah yang sangat baik walaupun usaha itu dilakukan secara ekstensif sekalipun. Potensi wilayah ini didukung oleh banyaknya padangpadang rumput yang luas dan iklim yang cocok untuk usaha peternakan (Sosroamidjojo, 1985)

Tujuan yang ingin dicapai dalam penelitian ini adalah 1) mengetahui potensi wilayah Kota Bukittinggi untuk pengembangan usaha ternak sapi potong sistem kreman dilihat dari aspek internal dan eksternal, 2) mengetahui kontribusi usaha ternak sapi potong terhadap pendapatan keluarga

\section{Materi dan Metode}

Penelitian dilakukan di Kota Bukittinggi dengan 3 kecamatan (Kecamatan Mandiangin Koto Selayan, Kecamatan Aur Birugo Tigobaleh, Kecamatan Guguk Panjang). Adapun pemilihan lokasi adalah berdasarkan pertimbangan letak dan keadaan alam yang strategis dalam pengembangan ternak sapi potong, khususnya dengan pola pemeliharaan secara kreman. $\mathrm{Hal}$ ini ditunjang pula oleh tingginya pemasaran daging di Kota Bukittinggi.

Penelitian menggunakan data primer dan data sekunder. Data primer digunakan untuk melihat kontribusi usaha ternak sapi potong kreman terhadap pendapatan keluarga peternak. Pengumpulan data primer dilakukan dengan wawancara terhadap peternak sebanyak 38 orang. Peternak ini dikelompokkan atas 3 strata berdasarkan jumlah sapi yang dipelihara, yaitu 1-3 ekor ekor (strata I), 4-6 ekor (strata II), $\geq 7$ ekor (strata III).

Untuk mengetahui besarnya kontribusi usaha sapi potong kreman terhadap pendapatan keluarga dilakukan perhitungan terhadap pendapatan dari usaha ternak sapi kreman, usaha tani dan sektor lain di luar usaha tani. Analisis data untuk mengetahui kontribusi usaha temak sapi potong kreman terhadap pendapatan keluarga menggunakan tabel frekuensi.

Data sekunder diperoleh dari lembaga/instansi terkait yang ada hubungannya dengan penelitian seperti Dinas Peternakan, BIPP dan Bappeda Kota Bukittinggi. Data sekunder digunakan untuk melihat potensi wilayah Kota Bukittinggi terhadap pengembangan usaha ternak sapi potong. Potensi wilayah tersebut dilihat dari faktor internal dan eksternal usaha ternak sapi potong.

Untuk faktor internalnya adalah ketersediaan pakan dan air, tenaga kerja, ketersediaan modal dan teknologi yang digunakan. Sedangkan faktor eksternalnya adalah iklim, topografi, aspek pasar, saranaprasarana, kelembagaan dan kebijakan pemerintah. Analisis data untuk mengetahui potensi wilayah dilakukan analisis deskriptif seperti rataan dan prosentase.

\section{Hasil dan Pembahasan}

\section{Potensi Wilayah Kota Bukittinggi}

Kota Bukittinggi merupakan salah satu dari 14 daerah TK II di propinsi Sumatera Barat: Daerah ini terletak lebih kurang $90 \mathrm{~km}$ dari ibukota propinsi dan terkenal sebagai Kota Tri Arga. Julukan ini muncul karena kondisi geografis kota yang dikelilingi oleh 3 buah gunung yaitu 
Gunung Singgalang, Gunung Merapi, dan Gunung Sago. Kota ini terletak pada ketinggian $909.21^{0}-100.25^{0}$ Bujur Timur dan $00.76^{\circ}-00.19^{\circ}$ Lintang Barat.

Kota Bukittinggi mempunyai luas daerah lebih kurang $25,239 \mathrm{~km}^{2}$. Luas tersebut merupakan $0,06 \%$ dari luas propinsi Sumatera Barat. Kota Bukittinggi terdiri dari 3 kecamatan, yaitu Kecamatan Guguk Panjang dengan jumlah kelurahan 7 buah, Kecamatan Mandiangin Koto Selayan yang merupakan kecamatan terluas dengan jumlah kelurahan 9 buah. Sedangkan kecamatan terkecil adalah Kecamatan Aur Birugo Tigobaleh yang mempunyai 8 buah kelurahan.

\section{Faktor Eksternal}

Topografi dan Iklim. Kondisi kelerengan di kota Bukittinggi $>40 \%$ berupa pegunungan dan bukit - bukit merupakan bagian yang cukup luas dari total luas wilayah. Kondisi ini merupakan peluang pengembangan ternak besar secara semi intensif.

Keadaan iklim di Kota Bukittinggi berkolerasi positif dengan letaknya dari permukaan laut, dengan ketinggian 909 - 914 meter menyebabkan daerah ini memiliki iklim pegunungan yang sejuk. Temperatur udara berkisar antara $16,1^{\circ}-24,1^{\circ} \mathrm{C}$. Sedangkan kelembaban udara berkisar antara $82,0 \%-90,8 \%$ dan tekanan udara antara $22^{\circ}-25^{\circ}$. Kondisi klimatologis diatas sangat potensial dalam pengembangan ternak sapi

Tabel 1. Populasi dan Pemotongan Sapi Potong per Kecamatan di Kota Bukittinggi Tahun 2006 pemeliharaan ternak sapi potong secara kreman.

Curah Hujan. Curah hujan adalah salah satu faktor klimatologis yang penting dalam pemeliharaan sapi potong. Curah hujan yang cukup akan sangat membantu peternak dalam penanaman pakan rumput terutama rumput jenis unggul seperti rumput raja dan rumput gajah. Kedua jenis rumput unggul tersebut paling banyak ditanam oleh peternak di Bukittinggi.

Pola curah curah hujan yang ada di Kota Bukittinggi menunjukkan daerah ini termasuk kategori wilayah beragroklimat basah.Tanah pertanian yang relatif subur dan ditunjang sebaran curah hujan yang cukup merata sepanjang tahun dengan curah hujan rata - rata $140,62 \mathrm{~mm}$ setiap bulan dan jumlah hari hujan 164 hari sepanjang tahun menjadikan wilayah ini sangat bagus untuk berbagai usaha komoditi pertanian termasuk peternakan.

Aspek Pasar. Pertumbuhan populasi dan pemotongan ternak sapi yang tidak seimbang merupakan masalah yang dihadapi wilayah ini setiap tahunnya. Belum sebandingnya kebutuhan dengan ketersediaan ternak sapi potong merupakan potensi pasar yang sangat bagus dalam pengembangan ternak sapi potong di Kota Bukittinggi. Pertumbuhan populasi dan pemotongan ternak sapi potong di Kota Bukittinggi terdapat pada tabel di bawah ini.

\begin{tabular}{llcccccc}
\multicolumn{10}{c}{ No } & \multicolumn{1}{c}{ Kecamatan } & \multicolumn{3}{c}{ Populasi Sapi Potong } & \multicolumn{2}{c}{ Pemotongan Sapi Potong } \\
\cline { 3 - 8 } & & Jantan & Betina & Jumlah & Jantan & Betina & Jumlah \\
\hline 1 & Guguk Panjang & 31 & 46 & 77 & 5.421 & 127 & 5.548 \\
2 & Mandiangin Koto Selayan & 164 & 153 & 317 & 559 & 0 & 559 \\
3 & Aur Birugo 13 & 57 & 44 & 101 & 351 & 0 & 351 \\
& Jumlah & 252 & 243 & 495 & 6.331 & 127 & 6.458 \\
\hline
\end{tabular}


Pada tabel terlihat jauhnya angka pemotongan temak sapi dibandingkan dengan populasi yang ada di wilayah ini. Untuk memenuhi kebutuhan daging ternak sapi, populasi yang ada di Kota Bukittinggi hanya 495 ekor dari 6.458 ekor kebutuhan pemotongan artinya baru $13,05 \%$ peternak di Kota Bukittinggi bisa memenuhinya, sementara 86,95 $\%$ dari kebutuhan tersebut terpaksa didatangkan dari luar daerah Kota Bukittinggi. Tingginya pemasaran daging di wilayah ini merupakan peluang yang sangat bagus dalam pengembangan usaha ternak sapi potong.

Secara garis besar peluang pasar yang besar untuk komoditi ternak sapi potong disebabkan oleh dua hal, yaitu:

a. Jumlah bakalan sapi potong dirasa belum mencukupi dan masih banyak yang didatangkan dari luar daerah Kota Bukittinggi

b. Dengan dikembangkannya program wisata di Bukittinggi menjadikannya potensi pasar bagi sektor pertanian/peternakan, sehingga produk pertanian/peternakan scara komperatif memiliki keunggulan karena dekat dengan pasar

Letak Kota Bukittinggi yang strategis yaitu di persimpangan jalan untuk keluar daerah (Sumatera Utara, Jambi dan Bengkulu) serta dikelilingi oleh Daerah TK II yang merupakan produsen ternak menjadikan Kota Bukittinggi sebagai pusat perdagangan temak dan hasil ternak. Disamping itu dalam menyongsong perdagangan bebas, Kota Bukittinggi merupakan pintu gerbang Sumatera Barat dalam perdagangan global.
Sarana dan prasarana. Menyikapi potensi Bukittinggi yang begitu strategis maka pembangunan dalam bidang peternakan diarahkan sesuai dengan sumber daya yang ada. Hal ini bagi pemerintah daerah menjadi motivasi untuk menyediakan sarana prasarana ternak dan hasil-hasilnya yang lebih representatif di Kota Bukittinggi sesuai dengan standar mutu yang telah ditetapkan baik teknis maupun higienis. Sarana tersebut diantaranya rumah potong hewan, pasar temak, tempat penjualan daging dan tempat penjualan hasil industri produk peternakan.

1. Rumah Potong Hewan

Rumah Potong Hewan yang ada di Bukittinggi berlokasi di Kecamatan Guguk Panjang. Perhatian pemerintah daerah terhadap sarana RPH sangat dibutuhkan dalam perbaikan pengadaannya disebabkan kondisinya yang tidak memadai karena sudah tua dengan fasilitas yang terbatas dan letaknya sudah ditengah kota sehingga mengakibatkan dampak lingkungan yang negatif.

2. Pasar Ternak

Pasar ternak di Bukittinggi berlokasi di Talas Kec. Guguk Panjang dengan luas lebih kurang 1Ha. Tingkat keberadaannya sangat menunjang dalam hal pemasaran ternak dan menarik minat pembeli untuk mencari bibit - bibit ternak yang akan digemukkan

Lokasi tersebut sangat strategis karena berada pada daerah yang mudah dijangkau sehingga memudahkan dalam hal transportasi dan pengangkutan ternak

Kegiatan pasar hewan sebenarnya pada hari Sabtu, tetapi satu atau dua hari sebelumnya kondisi pasar 
mulai aktif dimana pedagang sudah mulai menaruh ternak yang akan dipasarkan.

3. Los daging

Tempat penjualan daging biasanya berada dekat lokasi penjualan komoditi pertanian yang lain. Kondisi los daging yang ada di Kota Bukittinggi sudah merupakan peningkatan pengadaan fasilitas sehingga kebersihan higienis daging yang dipasarkan memenuhi standar kesehatan.

Aspek Kelembagaan. Sasaran dari program penyelenggaraan penyuluhan pertanian adalah petani - ternak dan keluarganya melalui pendekatan kelembagaan seperti terhadap kelompok tani. Pemberdayaan kelompok tani menjadi sasaran utama agar kelompok tani mampu melakukan inovasi baru, memanfaatkan fasilitas pelayanan teknis maupun kredit perbankan yang disosialiasikan melalui penyuluhan pertanian. Semua ini diperlukan petani-ternak dalam mengelola sumber daya alam untuk meningkatkan p;endapatan dan kesejahteraan keluarga.

Kelompok tani adalah wadah pemberdayaan bagi masyarakat tani dalam pelaksanaan usaha taninya. Prioritas pembangunan sektor pertanian tetap melalui pemberdayaan kelompok tani sebagaimana telah dijalankan pada program - program pemerintah daerah pada tahun sebelumnya. Untuk mendukung dan mempercepat usaha agribisnis di tingkat kelompok tani, orientasi pertumbuhan dan pembinaan kelompok tani lebih dititikberatkan kepada orientasi komoditi unggulan, artinya pengelompokkan petani dipicu atas dasar komoditi sentra produksi.

$$
\text { Idealnya kelompok tani }
$$
beranggota lebih kurang 15 sampai 20 orang dengan jenis komoditi tertentu. Beberapa kelompok tani dalam kawasan administrasi tertentu (kelurahan atau kenagarian) berhimpun dalam bentuk Himpunan Kelompok Tani atau Kelompok Usaha Bersama atau koperasi tani dan lain - lain) yang secara keseluruhan dibimbing langsung oleh penyuluh pertanian. Hal ini dilakukan agar masing - masing subsektor pertanian dapat berjalan dengan sinkron pada kawasan - kawasan sentra produksi secara terencana dan terarah.

Sarana kelembagaan dalam menunjang pengembangan berbagai komoditi pertanian peternakan masih sedikit terdapat di kota Bukittinggi. Untuk sub-sektor peternakan baru terdapat 1 buah rumah potong hewan yang letaknya sudah ditengah perkotaan sehingga menimbulkan ekternalitas terhadap lingkungan sekitar, sedangkan unit pembibitan ternak dan pos kesehatan hewan belum ada sama sckali.

Kebijaksanaan Pemerintah Kota Bukittinggi. Kebijaksanaan daerah merupakan acuan bagi semua sektorisub sektor dalam kegiatan pembangunan yang sedang berlangsung maupun yang akan dlakukan dalam jangka pendek dan jangka panjang. Tujuan Penyusunan Rencana Tata Ruang Wilayah adalah untuk mewujudkan rencana pemanfaatan ruang daerah Kota Bukittinggi secara terpadu, serasi dan optimal berdasarkan kesesuaian, daya dukung wilayah dan lingkungan serta kebijaksanaan nasional maupun daerah. Sektor pariwisata sebagai program utama daerah telah menimbulkan peningkatan kebutuhan berbagai komoditi pertanian diantaranya sayur - sayuran, buahbuahan daging dan lain - lain. 
Kegiatan yang diprioritaskan oleh Pemerintah Kota Bukittinggi di sektor peternakan untuk memenuhi kebutuhan akan daging adalah: perluasan tanaman rumput ternak, penambahan populasi ternak, melaksanakan Inseminasi Buatan untuk meningkatkan populasi sapi unggul sebagai bakalan, pemanfaatan optimal SDA seperti penggunaan lahan efisien dan pemanfaatan limbah pertanian dan limbah industri sebagai pakan tambahan sapi potong., pemantapan kaswasan sapi potong, pelatihan sapta usaha sapi potong dan agribisnis usaha ternak sapi potong. Semua kegiatan tersebut ditujukan untuk menunjang program parawisata yang didukung oleh potensi alam (iklim) dan pemasaran yang baik.

\section{Faktor Internal Usaha Sapi Potong.}

Pakan dan Air. Ketersediaan pakan dan air sangat erat kaitannya dengan luas dan penggunaan lahan pada sektor pertanian dan peternakan. Ketersediaan pakan dan air merupakan faktor internal yang berkaitan dengan faktor eksternal yaitu iklim dan topografi.

Keunggulan lain yang dimiliki
Kota Bukittinggi dalam pengembangan usaha peternakan khususnya ternak sapi potong secara kreman adalah tersedianya sisa hasil pertanian sebagai pakan tambahan bagi ternak sapi. Pakan tambahan sangat berpengaruh terhadap pertambahan bobot badan ternak sapi potong, salah satu contohnya adalah limbah industri kerupuk sanjai yang dapat dijadikan sebagai pakan konsentrat. Sebagai daerah penghasil produk pertanian, kotoran ternak diperlukan dalam menunjang pengembangan holtikultura dan sentra buahbuahan. Potensi ini dapat dikelola secara optimum bila keterkaitan antar komoditi ditata pada kawasankawasan sentra melalui keterpaduan progarm.

Besarnya luas lahan pertanian padi sawah dan lahan pertanian nonpadi merupakan potensi daerah yang memberikan peluang dalam pengembangan usaha ternak sapi potong di Kota Bukittinggi. Sawah sebagai usaha tanaman pangan membantu peternak dalam menyediakan pakan temak yang berasal dari produk sisa pertaniannya berupa dedak dan jerami. Dedak dapat digunakan sebagai pakan tambahan atau konsentrat sedangakan jerami membantu mencukupi kebutuhan ternak akan pakan rumput.

Semua limbah pertanian dapat membantu peternak di Bukittinggi dalam memenuhi kebutuhan ternak sapi terhadap pakan rumput dan konsentrat. Limbah pertanian berpotensi sebagai sumber pakan temak dan kotoran ternak berpotensi dalam pengembangan komoditas pertanian lain.

Limbah komoditi jagung berupa batang jagung mempeunyai peranan yang sangat penting sebagai sumber pakan ternak di wilayah Kota Bukittinggi. Batang jagung sangat potensial sebagai subtitusi pakan rumput. Berdasarkan pengalaman peternak pemakaian batang jagung sangat baik sebagai substitusi pakan rumput walaupun digunakan sampai $100 \%$

Dalam memenuhi kebutuhan air, petani memanfaatkan air sungai dan air hujan. Kota Bukittinggi memiliki dua buah sungai kecil yait batang Tambuo dan batang Sianok. Batang Tambuo yang mengalir di bagian timur kota dimanfaatkan untuk mengairi sawah. Sedangkan batang Sianok tidak banyak dimanfaatkan 
oleh petani karena berada pada daerah kerendahan.

Pemeliharaan ternak sapi potong di Bukittinggi menunjukkan kebutuhan yang tidak begitu besar terhadap air minum. Hal ini disebabkan karena kondisi iklim yang sejuk dan pemberian pakan konsentrat yang sudah dicampur dengan air.

Ketersediaan Tenaga Kerja. Sesuai dengan potensi yang ada, program Dinas Peternakan Kota Bukittinggi dalam pengembangan usaha ternak sapi potong, mengarahkan peternak agar memanfaatkan secara efisien waktu/jam kerja petani. Hal ini biasanya terdapat pada usaha tani terpadu, jadi dalam 1 hari kerja petani dapat mengelola berbagai macam komoditi pertanian. Antara masingmasing komoditi pertanian tersebut memiliki hubungan yang saling menguntungkan dan dapat meningkatkan pendapatan petani-ternak.

Ketersediaan Modal. Peternak sapi potong di Bukittinggi mempunyai modal dari beragam sumber, diantaranya adalah dari modal sendiri, modal orang lain dan ada bantuan modal dari pemerintah. Sumber dana yang digunakan untuk usaha pemeliharaan sapi potong dengan jalan memanfaatkan bantuan pemerintah disebut juga dengan sistim gaduhan. Keuntungan yang didapat diakhir periode pemeliharaan dibagi $70 \%$ untuk peternak dan $30 \%$ untuk pemerintah. Keuntungan yang diperoleh pemerintah sebesar $30 \%$ akan digilirkan kembali ke peternak lain. Program ini dijalankan pemerintah daerah untuk membantu petanipetani kecil dalam penyediaan ternak sapi bakalan.
Sistim pemeliharaan dengan jalan memanfaatkan sumber dana dari orang lain disebut sistem seduaan. Keuntungan yang didapat diakhir periode pemeliharaan dibagi $50 \%: 50$ $\%$ antara peternak dan sumber dana.

Kedua bentuk sumber modal yang telah digunakan oleh peternak sapi potong di Bukittinggi terbukti telah banyak membantu dalam hal permodalan. Modal pada usaha ternak sapi potong kreman umumnya berbentuk penambahan populasi ternak sapi bakalan. Biaya terbesar biasanya berasal dari pembelian sapi bakalan yang sesuai dan cocok schingga keuntungan akhir yang didapat peternak cukup baik.

Sedangkan modal untuk biaya pakan, obat - obatan dan biaya produksi lain masih bisa diusahakan sendiri oleh peternak. Untuk pakan rumput, peternak biasanya tidak membeli karena berasal dari lahan sendiri. Sedangkan biaya untuk pakan konsentrat tidak terlalu besar karena pemanfaatan limbah pertanian yang efektif dan efisien seperti kulit ubi kayu, ampas tahu dan dedak.

Penggunaan Teknologi. Sesuai dengan kebijakan Pemerintah Daerah TK II Bukittinggi yang disusun dalam Visi dan Misi Pembangunan Kota Bukittinggi tahun 2000 - 2005, maka pembangunan sub-sektor peternakan lebih diarahkan pada pembangunan peternakan rakyat dengan memanfaatkan teknologi tepat guna. Pemeliharaan ternak sapi potong sudah membudaya dengan penerapan teknologi pemeliharaan yang sudah dikuasai oleh peternak di Bukittinggi. Penerapan teknologi di setiap kecamatan dapat dilihat pada tabel berikut. 
Tabel 2. Penerapan Teknologi Pada Usaha ternak Sapi Potong per Kecamatan di Kota Bukittinggi

\begin{tabular}{llcccc}
\hline No & Kecamatan & \multicolumn{4}{c}{ Penerapan Teknologi (\%) } \\
\cline { 3 - 6 } & & Bibit Unggul & Pengadaan bibit dg IB & Pakan & Pemeliharaan \\
\hline 1 & MKS & 75 & 100 & 25 & 100 \\
2 & AB 13 & 70 & 100 & 25 & 100 \\
3 & GP & 80 & 90 & 30 & 90 \\
\hline
\end{tabular}

Tabel 3. Kontribusi Usaha Ternak Sapi Potong terhadap Pendapatan Keluarga

\begin{tabular}{crrc}
\hline Strata & Pendapatan Keluarga (Rp) & Pendapatan dari ternak sapi (Rp) & Kontribusi (\%) \\
\hline I & 9.225 .652 & 1.669 .006 & 18,09 \\
II & 13.715 .490 & 3.380 .140 & 24,64 \\
III & 9.391 .933 & 5.391933 & 57,41 \\
\hline
\end{tabular}

Tabel 2 menunjukkan penerapan teknologi pada usaha peternakan sapi potong di ketiga kecamatan sudah tinggi terutama dalam hal penggunaan bibit unggul, pengadaan bibit secara IB dan pemeliharaan. Sedangkan penanaman rumput sebagai sumber pakan utama ternak memang masih terbatas. Penggunaan lahan-lahan non produktif seperti tanggul saluran, lereng-lereng tebing dan pekarangan belum dimanfaatkan secara optimal. Inilah yang menjadi salah satu pembatas berkembangnya sapi potong. Potensi ini perlu dikembangkan oleh pemerintah dacrah sehingga penggunaan lahan bisa dilakukan secara optimum.

Penerapan teknologi pada pengadaan bibit dan pemilihan ras ternak sapi telah dilakukan peningkatan produktifitasnya oleh pemerintah daerah. Peningkatan produktifitas dan mutu genetik ternak dilakukan melalui program persilangan dengan teknologi IB. Beberapa pengalaman di lapangan memperlihatkan bahwa persilangan Simental lebih unggul dari bangsa pejantan lain (Brahman, Limousine, Charoloise, dan Ongole). Namun demikian untuk memprogramkan
Simmentalisasi memerlukan pengamatan efisiensi penggunaan pakan dan efisiensi usaha.

Peternak lebih menyukai ras Simental disebabkan oleh performannya yang bagus dan pertambahan bobot badannya yang lebih cepat. Keunggulan ras ini ditunjang oleh faktor iklim yang cocok dan teknis pemeliharaan yang baik sehingga usaha petemakan sapi potong di Bukittinggi sudah menjadi salah satu sumber pendapatan keluarga yang banyak diminati oleh petani-ternak di Bukittinggi.

\section{Kontribusi Ternak Sapi Kreman terhadap Pendapatan Keluarga}

Besarnya kontribusi usaha ternak sapi kreman terhadap pendapatan keluarga sagat ditentukan oleh pendapatan di luar usaha peternakan. Bukittinggi merupakan salah satu Daerah TK II di Sumatera Barat yang penduduknya sebagian besar bermata pencarian perdagangan.

Kontribusi usaha ternak sapi kreman bagi pendapatan keluarga petani ternak di Bukittinggi juga sangat ditentukan oleh potensi wilayah Kota Bukittinggi yang cukup terbuka, transportasi dan fasilitas yang lancar 
oleh petani karena berada pada dacrah kerendahan.

Pemeliharaan ternak sapi potong di Bukittinggi menunjukkan kebutuhan yang tidak begitu besar terhadap air minum. Hal ini disebabkan karena kondisi iklim yang sejuk dan pemberian pakan konsentrat yang sudah dicampur dengan air.

Ketersediaan Tenaga Kerja. Sesuai dengan potensi yang ada, program Dinas Peternakan Kota Bukittinggi dalam pengembangan usaha ternak sapi potong, mengarahkan peternak agar memanfaatkan secara efisien waktu/jam kerja petani. Hal ini biasanya terdapat pada usaha tani terpadu, jadi dalam 1 hari kerja petani dapat mengelola berbagai macam komoditi pertanian. Antara masingmasing komoditi pertanian tersebut memiliki hubungan yang saling menguntungkan dan dapat meningkatkan pendapatan petani - ternak.

Ketersediaan Modal. Peternak sapi potong di Bukittinggi mempunyai modal dari beragam sumber, diantaranya adalah dari modal sendiri, modal orang lain dan ada bantuan modal dari pemerintah. Sumber dana yang digunakan untuk usaha pemeliharaan sapi potong dengan jalan memanfaatkan bantuan pemerintah disebut juga dengan sistim gaduhan. Keuntungan yang didapat diakhir periode pemeliharaan dibagi $70 \%$ untuk peternak dan $30 \%$ untuk pemerintah. Keuntungan yang diperoleh pemerintah sebesar $30 \%$ akan digilirkan kembali ke peternak lain. Program ini dijalankan pemerintah daerah untuk membantu petanipetani kecil dalam penyediaan ternak sapi bakalan.
Sistim pemeliharaan dengan jalan memanfaatkan sumber dana dari orang lain disebut sistem seduaan. Keuntungan yang didapat diakhir periode pemeliharaan dibagi $50 \%: 50$ $\%$ antara peternak dan sumber dana.

Kedua bentuk sumber modal yang telah digunakan oleh peternak sapi potong di Bukittinggi terbukti telah banyak membantu dalam hal permodalan. Modal pada usaha ternak sapi potong kreman umumnya berbentuk penambahan populasi ternak sapi bakalan. Biaya terbesar biasanya berasal dari pembelian sapi bakalan yang sesuai dan cocok sehingga keuntungan akhir yang didapat peternak cukup baik.

Sedangkan modal untuk biaya pakan, obat - obatan dan biaya produksi lain masih bisa diusahakan sendiri oleh peternak. Untuk pakan rumput, peternak biasanya tidak membeli karena berasal dari lahan sendiri. Sedangkan biaya untuk pakan konsentrat tidak terlalu besar karena pemanfaatan limbah pertanian yang efektif dan efisien seperti kulit ubi kayu, ampas tahu dan dedak.

Penggunaan Teknologi. Sesuai dengan kebijakan Pemerintah Daerah TK II Bukittinggi yang disusun dalam Visi dan Misi Pembangunan Kota Bukittinggi tahun 2000 - 2005, maka pembangunan sub-sektor peternakan lebih diarahkan pada pembangunan peternakan rakyat dengan memanfaatkan teknologi tepat guna. Pemeliharaan ternak sapi potong sudah membudaya dengan penerapan teknologi pemeliharaan yang sudah dikuasai oleh peternak di Bukittinggi. Penerapan teknologi di setiap kecamatan dapat dilihat pada tabel berikut. 
Tabel 2. Penerapan Teknologi Pada Usaha temak Sapi Potong per Kecamatan di Kota Bukittinggi

\begin{tabular}{llcccc}
\hline \multirow{2}{*}{ No } & Kecamatan & \multicolumn{4}{c}{ Penerapan Teknologi (\%) } \\
\cline { 3 - 6 } & & Bibit Unggul & Pengadaan bibit dg IB & Pakan & Pemeliharaan \\
\hline 1 & MKS & 75 & 100 & 25 & 100 \\
2 & AB 13 & 70 & 100 & 25 & 100 \\
3 & GP & 80 & 90 & 30 & 90 \\
\hline
\end{tabular}

Tabel 3. Kontribusi Usaha Ternak Sapi Potong terhadap Pendapatan Keluarga

\begin{tabular}{crrc}
\hline Strata & Pendapatan Keluarga (Rp) & Pendapatan dari ternak sapi (Rp) & Kontribusi (\%) \\
\hline I & 9.225 .652 & 1.669 .006 & 18,09 \\
II & 13.715 .490 & 3.380 .140 & 24,64 \\
III & 9.391 .933 & 5.391933 & 57,41 \\
\hline
\end{tabular}

Tabel 2 menunjukkan penerapan teknologi pada usaha peternakan sapi potong di ketiga kecamatan sudah tinggi terutama dalam hal penggunaan bibit unggul, pengadaan bibit secara IB dan pemeliharaan. Sedangkan penanaman rumput sebagai sumber pakan utama ternak memang masih terbatas. Penggunaan lahan-lahan non produktif seperti tanggul saluran, lereng-lereng tebing dan pekarangan belum dimanfaatkan secara optimal. Inilah yang menjadi salah satu pembatas berkembangnya sapi potong. Potensi ini perlu dikembangkan oleh pemerintah daerah sehingga penggunaan lahan bisa dilakukan secara optimum.

Penerapan teknologi pada pengadaan bibit dan pemilihan ras ternak sapi telah dilakukan peningkatan produktifitasnya oleh pemerintah dacrah. Peningkatan produktifitas dan mutu genetik ternak dilakukan melalui program persilangan dengan teknologi IB. Beberapa pengalaman di lapangan memperlihatkan bahwa persilangan Simental lebih unggul dari bangsa pejantan lain (Brahman, Limousine, Charoloise, dan Ongole). Namun demikian untuk memprogramkan
Simmentalisasi memerlukan pengamatan efisiensi penggunaan pakan dan efisiensi usaha.

Peternak lebih menyukai ras Simental disebabkan oleh performannya yang bagus dan pertambahan bobot badannya yang lebih cepat. Keunggulan ras ini ditunjang oleh faktor iklim yang cocok dan teknis pemeliharaan yang baik sehingga usaha peternakan sapi potong di Bukittinggi sudah menjadi salah satu sumber pendapatan keluarga yang banyak diminati oleh petani-ternak di Bukittinggi.

\section{Kontribusi Ternak Sapi Kreman terhadap Pendapatan Keluarga}

Besarnya kontribusi usaha
ternak sapi kreman terhadap
pendapatan keluarga sagat ditentukan oleh pendapatan di luar usaha peternakan. Bukittinggi merupakan salah satu Dacrah TK II di Sumatera Barat yang penduduknya sebagian besar bermata pencarian perdagangan.

Kontribusi usaha temak sapi kreman bagi pendapatan keluarga petani ternak di Bukittinggi juga sangat ditentukan oleh potensi wilayah Kota Bukittinggi yang cukup terbuka, transportasi dan fasilitas yang lancar 
serta dekat dengan pusat kegiatan ekonomi. Semua sarana dan prasarana tersebut memungkinkan petani-ternak menjangkau dan menggali sumber pendapatan di luar pertanian/ peternakan. Hal ini juga sangat dipengaruhi oleh kenyataan dengan terbatas lahan yang digarap. Rata-rata kontribusi usaha ternak sapi kreman per periode pemeliharaan dapat dilihat pada tabel berikut.

Pada tabel diatas terlihat peternak pada strata $I$ (pemeliharaan 1-3 ekor) memiliki kontribusi terhadap pendapatan keluarga sebesar 18,09\%, peternak pada strata II (pemeliharaan 4-6 ekor) $24,67 \%$ dan peternak pada strata III ( pemeliharaan $\geq 7$ ekor) $57,41 \%$. Kondisi diatas menggambarkan dengan semakin meningkatnya jumlah sapi akan meningkatkan kontribusi usaha peternakan terhadap pendapatan keluarga. Walaupun ketersediaan lahan yang terbatas, petani ternak di Bukittinggi mampu memanfaatkan potensi yang ada seefisien dan seefektif mungkin dalam pengembangan sektor pertanian dan peternakan sehingga dapat memberikan kontribusi yang nyata terhadap pendapatan keluarga.

\section{Kesimpulan}

Potensi wilayah Kota Bukittinggi sangat mendukung dalam pengembangan usaha ternak sapi potong secara kreman baik ditinjau dari faktor eksternal (iklim, topografi, aspek pasar, sarana - prasarana, kelembagaan dan kebijakan pemerintah) maupun faktor internal (ketersedian pakan dan air, ketersediaan tenaga kerja, ketersediaan modal dan teknologi yang digunakan. Sedangkan kontribusi yang diberikan olch usaha ternak sapi kreman terhadap pendapatan keluarga petani adalah; strata $118,09 \%$, starta II $24,67 \%$ dan strata III $57,41 \%$.

\section{Daftar Pustaka}

Balai Informasi dan Penyuluhan Pertanian (BIPP) Daerah TK. II Bukittinggi, 2000. Data Potensi Wilayah. BIPP. Bukittinggi.

Dinas Peternakan TK.I Provinsi Sumatera Barat. 2006. Statistika Peternakan Provinsi Sumatera Barat.

Dinas Peternakan TK.II Kota Bukittinggi. 1998. Program Penyelenggaraan Penyuluh Pertanian Kota Bukittinggi. Bukittinggi

Santosa, U. 1999. Prospek Agribisnis Usaha Ternak Pedet. Penerbit Penebar Swadaya, Jakarta.

Sosroamidjojo, S. 1985. Ternak Potong dan Kerja. Cetakan ke-10. Penerbit PT. Raja Grafindo Persada, Jakarta.

\author{
Alamat korespondensi: Yetmaneli, S.Pt, MP \\ Jurusan Produksi Temak Fakultas Petemakan \\ Universitas Andalas, Kampus Limau Manis \\ Padang
}

Diterima: 2 Januari 2007, Disetujui: 30 Januari 2007 